IBT Journal of Business Studies (IBT-JBS)

E-ISSN: 2409-6520; P-ISSN: 2414-8393

Volume 16:, 125-140 (2020)

DOI: $10.46745 /$ ILMA.jbs.2020.161.01

\title{
Valuation of Equity Securities, Private Firms, and Startups
}

\author{
Received: 20-Jun-2020 | Accepted: 10-Jul-2020 \\ Syed Babar Ali' ${ }^{*}$ iD $\mid$ Manzoor A. Khalidi² iD
}

\begin{abstract}
For valuation of equity securities and similar objects research has not been rigorous and holistic. This paper is an attempt to review the literature on valuation of equity for a variety of types of entities, and within some important valuation contexts. The review was performed for such themes as (1) Valuation of Stocks (2) Valuation of Private Firms (3) Valuation of Startups (4) Valuation in Emerging Markets (5) Valuation and IPO. The review found that there is a consensus over various models for their usefulness and theoretical soundness, at the same time researchers and practitioner are seeking better models, particularly in the areas of private firm valuation and startups. The valuation of stock has more robust and recognized framework as compared to private firms and startups. The valuation of private firms is more complex because of closed nature of the firm. The valuation of startup is complicated because of the newness of the business and industry, and also because of the nature of the business structure. In general, the practices involving valuation of equity securities and other similar entities have evolved and improved over time. This research will enable the security analysts and other valuation experts to gain insights into various models and their inputs for their beneficial applications.
\end{abstract}

Keywords: Valuation of Securities, Valuation of Private firms, Valuation emerging markets, Valuation of startups, and Valuation and IPO.

JEL Classification: $D 63, D 21, D 22, D 53, F 36, G 32$

$\begin{array}{ll}\text { Author's Affiliation: } & \\ \text { Institution: } & \text { Barret Hodgson University } \\ \text { Country: } & \text { Pakistan } \\ \text { Corresponding Author's Email: } & \text { *baberali@bhu.edu.pk }\end{array}$

The material presented by the author(s) does not necessarily portray the view point of the editors and the management of the ILMA University, Pakistan.

2409-6520 (Online) 2414-8393 (Print) (C2020, published by the ILMA University, Pakistan.

This is open access article under the @- $\odot$ license. https://creativecommons.org/licenses/by/4.0/

Page $\mid 125$ 


\section{1) INTRODUCTION}

\section{1) BACKGROUND}

Valuation is a very broad area in finance, the scope of which ranges from valuation of simple financial instruments such as corporate bonds to valuation of startups to valuation of very complex financial instruments such as derivatives securities (Hitchner, 2017). There are various frameworks and models available to perform valuation. The frameworks are mostly quantitative in nature but qualitative frameworks also exist. Then there are a number of models available within quantitative and qualitative frameworks. Within quantitative models we have fundamental analysis and technical analysis. Within fundamental analysis we have absolute methods and relative valuation methods. The use of a particular framework depends upon the nature of the valuation object and the nature of the context. Therefore, a single framework or a model cannot be universally applied with much confidence and effect (Fazzini, 2018). There are various challenges faced in the valuation process. The accuracy and relevance of valuation depends on the expertise and judgement of the individual/s involved, accurate estimation and determination of the input, reasonable estimation of cash flows, and availability of sufficient and accurate information (Damodaran, 2012).

Even though valuation of publicly held securities involves numerous variables it is a simpler task as compared to valuation of a private firm, private equity, and startups. This is because the context within which the valuation is performed is quite complex, broad, unstable, but at the same time very relevant (Trugman, 2017). Therefore, a number of additional themes, comprising the valuation context, such as emerging markets, and Initial Public Offering have been discussed in this study. In a general sense valuation is performed for an optimal investment decision.

\section{2) THE NATURE OF VALUATION}

For investment in any asset, it is very important to understand that success lies in not only knowing the value but also having a good understanding of where the value comes from (Kazlauskienè \& Christauskas, 2008). Any type of asset can be valued, but some assets can be easily valued while the others are found very difficult to be valued. The specifications of valuation will naturally vary from one asset to another. The level of similarity existing for fundamental principles, however, is somewhat surprising given the significant dissimilarities among the valuation techniques for the universe of assets (Mcallister, 1995). There will always be some extent of uncertainty related to the valuation numbers. This is because the analysts have to make several assumptions about the prospects of the company, industry, and the economy, and elated to the inputs to the valuation model (Cassia, Plati, \& Vismara, 2007). As a valuation model becomes more sophisticated, the required number of inputs increases, making it more vulnerable to estimation errors. (Dechow \& You, 2013). There are some important principles in this regard such as principle of parsimony, (Brennan \& Schwartz, 1984), principle of trade-off, and the appreciation that the staff rather than the models perform valuation. 


\section{3) PURPOSE}

This study has been written to review the literature on valuation of equity securities, private firms, startups and the context surrounding the valuation of these objects.

\section{2) REVIEW APPROACH}

\section{1) ORGANIZED LITERATURE REVIEW}

An organized literature review of specific themes related to valuation of equity and was equity was performed to accumulate the relevant findings. It is well understood in the literature that a rigorous, extensive, and organized literature review is a forceful mechanism to produce a meaningful overview of literature related to a specific area (Rousseau \& Mccarthy, 2007) and (Köhn, 2018). As per my understandings paper this is the only holistic and systematic review on the valuation of equity and related subjects.

\section{2) ARTICLE FOCUS}

To perform a review of the literature on the broad area of valuation as it relates to equity valuation, directly and indirectly, a systematic search was conducted between the period of early April to late October 2018.

\section{3) ARTICLE IDENTIFICATION AND SELECTION}

A four-step process for identification and selection of relevant articles, on the lines of (Bouncken \& Gast, 2015) was employed. The first step involved searching various databases such as Google Scholars, Emerald, JSTOR, Elsevier, Springer, Taylor Francis, and Social Science Research Network, for various key words. Eliminating double counts, this initial step produced a sample of about 800 articles and books. The screening activities such as initial screening, reviewing, scrutinizing, quality cut-off were applied resulting in a tally of 55 papers.

\section{3) LITERATURE REVIEW}

\section{1) THEME: 1 VALUATION OF STOCKS}

\subsection{1) VALUATION METHODS}

Research on the use of valuation method is scare and not definite. There are four major valuation approached employed by analysts to find value of equity or the firms. (Bradshaw, 2004) state that only about half of the 104 analysts' reports investigated claim using full-fledged Discounted Cash Flow (DCF) valuation approaches. He added that these valuation approaches include two variants of the DCF residual income-based model, some variant of Price-earnings over Growth (PEG) ratio, and analysts' estimation of the long-term earnings growth. Which $\mathrm{method} / \mathrm{s}$ is/are selected by analysts depend on the overall context including analyst 
own familiarity, and clients' acceptability. The analyst employ customization to the valuation methodologies to a specific industry. Following their own environment some analysts use DCF models, while others employ elaborate analyses based on price-to-sales multiples, profitability analysis or growth options (Demirakos, Strong, $\&$ Walker, 2004). The use of Residual Income Model (RI) is not so common but the support is increasing (Saleh, 2017). The consideration of the context is acceptable in the practice of valuation as the analysts are not required to precisely discover valuation, but there job is to actually challenge the market price (Penman, 2016). The discussion on the analysts' context was stressed more by (Demirakos, Strong, \& Walker, 2010) who stated that operational size, level of earnings, adequate size of the industry peers and yearly market return, and level of complexity as important determinants for the choice of a valuation model. Similar arguments were presented by (Imam, Barker, \& Clubb, 2008) who interviewed the sell-side analysts, and performed content analysis of equity research reports to find DCF methods as favorites for analysts because of their flexibility. This aspect of analysts' preference has been ignored by the previous research.

Although the flexibility of DCF methods promote their widespread adoption they do not necessarily produce more accurate target prices as compared to PE models. Moreover, the use of DCF models is significantly more than the PE models for highly risky firms, small-sized firms, firms with negative earnings, firms with volatile growth, firms with only a few industry peers, and in rising markets (Demirakos, Strong, \& Walker, 2010). Analysts generally use multiple methods to obtain confirmation of the accuracy of their valuation. The use of multiple methods is evident from studies such as from (Jerald, Robinson, \& Stowe, 2015) who surveyed investment analysts to report that $(92.8 \%)$ of them employed multiple methods, (78.8\%) employed DCF methods, (61.4\%) employed asset-based approaches, and the remaining employed other methods.

\subsection{2) VALUATION INPUTS}

The process of the process of estimating valuation parameters is as important as the valuation itself (Bancel \& Mittoo, 2014). As the valuation of a financial asset involves projections that require judgments it is considered as an art rather than science. This makes the current valuation models more valuable as they provide convenient flexibility. According to (Kolouchová \& Novák, 2010), as is mentioned in the previous research, the risk-free rate used in capital Asset Pricing Model (CAPM) was often based on 10-year long term bond, either of the domestic or foreign government. This concur with the argument of (Brotherson, Eades, Harris, \& Higgins, 2013) suggesting that risk-free rate should match the yield on the Treasury bond of US government having a maturity of ten years or more.

Existing literature suggests that, in practice, there are a lot of issues in the determination of market risk premium both as to its value and methods of estimation (Brotherson, Eades, Harris, \& Higgins, 2013). Some studies such as (Damodaran, 2008) consider estimation of equity risk premium as haphazard with valuation practitioners using a range of data periods, risk-free rates, and index returns. Similarly, (Kolouchová \& Novák, 2010) also points out to the fact that the 
estimation of equity risk premium is performed through historical data. In terms of employing a proxy for beta factor, experts generally use industry beta.

(Green, Hand, \& Zhang, 2016) using a sample of 120 sell-side analyst reports, containing DCF model, investigated into execution errors and questionable economic judgments per DCF. The errors included using higher risk-free rate, a very high growth rate, applying no adjustment to cash flows and the initial equity value. According to (Brotherson, Eades, Harris, \& Higgins, 2013) the following represent the "best current practice" in the estimation of WACC: Market-value based weights for debt and equity; the cost of debt should involve taxes; CAPM is commonly used for the estimation of the cost of equity; the values of betas are obtained from published sources. However, the best practice would involve judgment of the experts to estimate the value of beta.

\section{2) THEME 2: VALUATION OF PRIVATE FIRM}

There are generally three traditional private company valuation approaches prevalent with the valuation expert: (1) Income Approach (2) Market Approach (3) Asset-based Approach. The choice of the approach depends on factors such as size, nature of operations and stage in the lifecycle (Rath, Raymond D, 2010). As the private company's earnings may contain inefficiencies and redundancies, there must be an adjustment to normalize the earnings for such items as management compensation, entertainment expenses and the value of real estate. Moreover, there could be adjustments related to the choice inventory methods, depreciation methods and issues related to capital expenditures. If the financial statements are not audited rather reviewed or even compile more adjustments might be needed (Rath, Raymond D, 2010). Cash flow estimation could be very challenging particularly for a firm in developmental stage or in mature stage, and using scenario analysis to estimate cash flows could be a good idea.

\subsection{1) INCOME APPROACH}

Income approach is based on the theory that the value of an asset is the present value of the future economic befits associated with owning the assets. There are three methods within the income approach (Rath, Raymond D, 2010): (1) Free cash Flow or Discounted Cash Flow Methods (2) Capitalized Cash Flow Method (3) Excess Earnings Method. The free cash flow method is based on discounting those cash flows using an appropriate discount rate over a horizon of 5 to 10 years. In a capitalization method, the value of the firm is determined discounting a single representative economic using an appropriate discount rate. In the residual income approach the value of the firm is the sum of the present value of the excess earnings, and the value of the operating assets. 


\subsection{2) REQUIRED RATE OF RETURN: MODELS AND ESTIMATION ISSUES}

It is not advisable to use CAPM method to estimate required rate of return for a private firm with its small size, and having no intention of going public (Rath, Raymond D, 2010). Similarly, (Canefield, Kruschwitz, \& Loffler, 2014) state that investors who are interested in privately held companies should not discount the cash flows using the standard CAPM model as it will imply the assumption that the investors are perfectly diversified. Instead of a CAPM method, an expanded CAPM method - with size premiums and other specific risks incorporated - could be used (Rath, Raymond D, 2010). Another factor to be considered while estimating the required rate of return for a private firm is that the cost of debt for a private firm is high without the sufficient access to the debt market, and their small size result in higher operating risk. Moreover, lack of information creates projection risk (Damodaran, 2012). One of the most innovative direction in the literature of private company valuation is the addition of "Implied Private Company Pricing Line" ("IPCPL"). Developed by (Dohmeyer \& Butler, 2013) it works on the insight that if there are no arbitrage opportunities between public and private equity markets, then under existing asset pricing theory there must be a systematic relationship between equity pricing in the two markets (Goodman \& McLelland, 2016). Taking the (IPCPL) theory forward (Goodman \& McLelland, 2016) developed an econometric model to estimate the required return for the valuation of a private firm.

\subsection{3) MARKET APPROACH METHODS OF PRIVATE COMPANY VALUATION}

The market approach employs direct comparisons to the publicly held companies or acquired enterprises to value the privately held companies. There are three methods available to value a privately held company (Rath, Raymond D, 2010): (1) Guideline Public Company Method (2) Guideline Transaction Method (3) Prior Transaction Method. Guideline public method employs the observable multiples from the comparable public company to value a private company and requires inclusion of a control premium (Feldman, 2005). Guideline transaction requires consideration of synergies, staleness, and some special consideration in the price, present in the transactions (Damodaran, 2012).

\subsection{4) ASSETS-BASED APPROACH TO PRIVATE COMPANY VALUATION}

It is rarely used for valuation of going concern privately held companies as the market data might not be available (Rath, Raymond D, 2010), moreover, information to value the business as an integrated whole would instead be available more easily. But if the business is under distress and the value of the individual assets is more than the value of the business as a whole, the asset based approach should be used (Damodaran, 2012). 


\section{3) THEME 3: VALUATION OF START-UPS}

The literature related to corporate finance discusses four valuation methods which are commonly used for startup valuation; these methods are: discounted cash flow valuation method, price earnings multiple based methods, net assets-based methods, and venture capital method. But, as the discussion follows, hardly any of these methods is considered anything close to satisfactory by new entrepreneurial firms (Ge, Mahoney, \& Mahoney, 2005). One of the assumptions behind these financial valuation methods is that the financial markets are efficient, which is not a reasonable assumption for the assets operating in capital markets involving new ventures (Lerner, Sørensen, \& Strömberg, 2008). These new ventures have a limited operating history and pose difficulties for the VC to obtain desirable information; therefore, it is quite difficult to estimate cash flows, and the inputs to determine the appropriate discount rate (Milanesi, Pesce, \& El Alabi, 2013). As for the calculation of price earnings multiple approach, there are several additional problems such as defining the range of the multiples used, and even choosing the multiples.

Generally speaking, qualitative factors are ignored in a conventional valuation framework. In fact, most of the studies which employed accounting-based valuation assume the value from non-accounting information as zero (Darrough \& Ye, 2007). As VC firms generally do not have cash flows, therefore researchers have sought extended accounting-based models to value venture capital firms. In this regard, (Sievers, Mokwa, \& Keienburg, 2013) have extended the work of (Hand, 2005) as well as (Armstrong, Davila, \& Foster, 2006) by incorporating the impact of such management characteristics as composition of the teams, education of the CEOs, or experience of the team. Majority of the equity and business valuation approaches and methods were constructed for well-established companies operating in the e $\square$ cient public equity markets. Realizing that (Miloud, Aspelund, \& Cabrol, 2012) developed a framework by integrating well-recognized theories in strategic management with important performance specific variables to estimate the valuation for a venture in its early stage of development. The study from (Ge, Mahoney, \& Mahoney, 2005) already supported the argument that strategic management theories are effective for the use in the valuation of start-ups. This linkage enables development of an effective approach to achieve identification and measurement of factors significant to the valuation of new ventures. As argued by (Dittmann, Maug, \& Kemper, 2004) venture capitalists who develop and maintain their investment strategies perform better than venture capital investors employing short-term, and subjective bargaining tactics.

Other than the conventional methods, literature has discussed several valuation methods which incorporate both quantitative and qualitative factors. There are popular quantitative methods such as Venture Capital Method, and First Chicago Method, as well as qualitative methods such as Scorecard Method, Berkus Method, and Risk Summation Method. Venture Capital and First Chicago Methods are variants of DCF; in the case of venture capital method valuation is performed in terms of various financing stages, whereas in the case of First Chicago method a number of economic scenarios are used to value the startup. The scorecard method and Berkus methods use qualitative factors such as the quality of teams, product, 
technology, initial sales, and market to value a startup (Nasser, 2010). These methods are particularly useful for the valuation of early-stage startups for two reasons. First the conventional quantitative methods are difficult to be used because of the unavailability of information needed for the estimation of cash flows. Secondly, the nature of a startup is such which requires evaluation of a number of interrelated qualitative factors (Köhn, 2018).

\section{4) THEME: 4 VALUATION IN EMERGING MARKETS}

Valuation practices in emerging markets suffer from a number of issues, nevertheless, there are some similarities in the emerging market valuation practices and those that prevail in the developed countries. A survey of fifty-five Argentinian companies by (Pereiro, 2006) revealed that their valuation practices were significantly consistent with that in U.S, in terms of the usage of the DCF, and the CAPM. This is consistent with the earlier study from (Bekaert, Erb, \& Harvey, 1997).

As mentioned above, the valuation practices in emerging markets are not without serious issues. (Damodaran, 2009) has identified four issues - unstable local currencies making the estimation of the risk-free rates difficult, an additional risk in country risk, availability of important information, and weak corporate governance. Some other emerging market valuation issues have been discussed in details in the study by (Bruner, Conroy, Estrada, Kritzman, \& Li, 2002) who stated that the difference between emerging markets and developed markets comes from areas such as financial disclosures, liquidity, corruption, market volatility, governance, tax environment, and transaction costs, which require a thorough consideration while applying various valuation approaches. (Sanchez, Preve, \& Allende, 2010) not only acknowledge these factors but also emphasized on the higher probability of financial crisis. Because of the existence of these issues, prices in emerging markets are discounted heavily by the foreign investors, and considerably by the local investors. The discount rate estimated for the valuation is not without issues as well. According to (Montalván \& Sarrió, 2006) the discount rate is estimated based on two assumptions for risk: market completeness, and existence of well-diversified investors. These two do not hold for emerging markets having restrictions on shortselling and borrowing, and having abundance of non-diversified investors.

All of these issues warrant an appropriate model for the valuation of firms and equity in emerging markets. To this effect (Damodaran, 2009) proposed a systematic framework for valuing emerging market companies employing specific risk-free rate, country risk premium, using sector-based beta, and incorporating the impact of country risk. While adjustment of country risk premium, in the estimation of discount rate, has been proposed generally (Sanchez, Preve, \& Allende, 2010) argued against it, as according to them country risk could be diversified and is not the same for each firm or industry. They rather proposed a valuation employing country risk through conditional cash flows. 


\section{5) THEME: 5 VALUATION AND INITIAL PUBLIC OFFERING (IPO)}

Researchers regard that valuation of IPOs has a significant position in the field of finance, probably as it provides a capability to the market participants - otherwise non-existing - to value the firms as a collection of complimentary assets. Valuation for IPOs is very important as the managers are able to, through signals from capital markets, to validate their views about the firm's future performance (Aggarwal, Bhagat, \& Rangan, 2009).

A comparable firm multiples method is recognized by researchers and practitioners across the world (Sahoo \& Rajib, 2013). This popularity has a lot to with its simplicity and the availability of information required for the implementation of this approach. It is obvious that IPOs are young and growing firm with limited operating history, and therefore estimating the payoffs is not easy. Furthermore, little guidance is available through the literature for determining the appropriate discount rate for IPOs (How, Lam b, \& Yeo, 2007). The use of multiples with historical data has been criticized by (Kim \& Ritter, 1999), however, they argue that the use of historical accounting information when leverage effects are controlled, could allow the enterprise value-to-sales ratio to produce good results.

(Bonaventura \& Giudici, 2016) analyzed the valuation approaches for the Italian companies during the period 2000-2009, and found the discounted cash flow method as the most widely used valuation techniques. Similarly, (Cogliati, Paleari, \& Vismara, 2011) have also identified the popularity of DCF method among the IPOs.

Various theories have been presented for IPO underpricing (Welch \& Ritter, 2002). The most acknowledged among them are the hypotheses such as riskaverse underwriter, the band-wagon, the asymmetric information hypothesis, and the ownership dispersion. The most dominating theory for the analysis of IPO underpricing, though, is signaling theory (Certo, Daily, \& Dan, 2003). This theory has found various applications (Lee, 2001) particularly in the IPO context. The theory is based on the requirement to eliminate the above-mentioned asymmetry problems, and argue that there are indicators which provide information about the performance potential and hence about future value of the firms (Deeds, Decarlois, \& Coombs, 1997).

\section{4) CONCLUSION}

The literature related to equity valuation has evolved over time with various dimension and there are several areas in the literature which can be associated with equity valuation. This study is a serious attempt to review valuation specific to selected themes as follows:

(1) Valuation of Stocks (2) Valuation of Private Firms (3) Valuation of Start-ups (4) Valuation in Emerging Markets and (5) Valuation and IPO. 
IBT JOURNAL OF BUSINESS STUDIES (IBT-JBS) Volume 16 Issue 1, 2020

An organized literature review of specific themes related to valuation of equity was performed to gather the relevant findings. A rigorous, extensive, and organized literature review is a forceful mechanism to produce a meaningful overview of literature related to a specific area. As per my understanding this paper is the only holistic and systematic review on the valuation of equity and related subjects.

To perform a review of the literature on the broad area of valuation as it relates to equity valuation, directly and indirectly, a systematic search was conducted between. This process was characterized by a four-step process such as searching, screening, reviewing and scrutinizing the literature, and application of a quality cut-off. Finally, the number of papers remaining to be reviewed was 125 .

\section{1) SUMMARY AND DISCUSSION}

\subsection{1) VALUATION OF STOCK: MODELS, INPUTS, AND THE ANALYST}

DCF methods are most commonly used. Multiples are also used significantly. Some analysts also use variants of the residual income-based model. Operational size, level of earnings, presence of industry peers and yearly market return, and level of complexity, social environment, and analyst motivation are important determinants for the choice of a valuation model. Although, flexible and acceptable, DCF model is not considered as a very accurate model. Among the multiples, the most popular ones are the $\mathrm{P} / \mathrm{E}$ and enterprise value multiples. The multiple-stage models are generally used, and within DCF methods majority used free cash flow approach.

The risk-free rate used in CAPM is commonly based on 10-year long term treasury bond's yield. The determination of equity market risk premium involves considerable controversy both as to its value and method of estimation. In terms of employing a proxy for beta factor, experts generally use industry beta. The best current practice" in the estimation of WACC: Market-value based weights, the inclusion of relevant taxes, the usage of CAPM, and use of betas from published sources.

\subsection{2) PRIVATE COMPANIES, AND STARTUPS - VALUATION CHALLENGES AND MODELS}

Valuation of these entities is generally complex and very challenging. The conventional valuation models don't work well for them. The challenges are similar but vary in intensity. The following is a summarized version of the review.

The literature discusses conventional as well as customized and innovative methods which are commonly used for startup valuation. But, none of these methods are considered satisfactory by new entrepreneurial firms. One of the assumptions behind these financial valuation methods is that the financial markets are efficient, which is reasonable only in the case of markets which are transparent, liquid, and regulated. This makes the estimation of future cash flows and valuation of intangible assets for a new venture to be quite complex. As for price earnings multiple approach, there are several problems such as no historical earnings, impracticality and subjectivity in using multiples. Excepts a few efforts the extant research does not discuss much 
what, and how, some factors impact the economic valuation of start-ups.

There are generally three traditional private company valuation approaches prevalent with the valuation expert: (1) Income Approach (2) Market Approach (3) Asset-based Approach. The choice of the approach depends on factors such as size, nature of operations and stage in the lifecycle. As the private company's earnings may contain inefficiencies and redundancies, adjustment to normalize the earnings are generally applied to items various expense and assets items. Instead of using CAPM method, an expanded CAPM method - where premium for size and company specific risks are added - might be suitable. One of the most innovative direction in private company valuation is the addition of "Implied Private Company Pricing Line" ("IPCPL"), which delineate a systematic relationship between equity pricing in the public and private. In the market approach a control premium is to be added. Also, it is important to incorporate the impact of the premium for expected synergies, stale transactions, and other considerations in the price.

\subsection{3) VALUATION AND EMERGING MARKET}

In emerging markets, the use of discounted cash-flow techniques is quite common, and a remodeled CAPM, incorporating country risk premium, is widely used to estimate the discount rate. There are various issues such as unstable currencies, country risk, unavailability of information, liquidity, tax environment, segmentation of the market, transaction cost, and weak corporate governance. Because of all this, emerging markets prices in the financial markets are heavily discounted by the investors. With higher probability of financial crisis, a valuation framework based on conditional cash flows could be used. A sector-based beta is recommended for avoiding skewness emerging from using a local index.

\subsection{4) VALUATION OF IPO}

The DCF method has been found as the most widely used valuation techniques in the IPO prospectus for the valuation, and forecast error larger for the firms with higher growth and higher debts. Comparatively, IPO firms usually show better operating performance preceding the listing, but not so after the listing. Various theories have been presented for IPO underpricing, the most dominating theory, though, is signaling theory. This theory implies that there are indicators which provide information to prospective investors related to estimating the future value of the firms.

\section{2) FINAL WORD}

Valuation is a very important area in the field of corporate finance, financial markets, investments, and personal finance. Its application is wide, generally, and also specifically for common equity securities, and objects having similar characteristics as common equities. While selection and application of valuation models is very important, the expertise and the context of valuation is also important aspects of valuation. The valuation of stock has robust and acknowledged framework as compared to private firms, firm equity, and startups. The valuation of private firms 
is more complex because of closed nature of the firm. The valuation of private equity and startup is complex because of the newness of the business, industry, and also because of the nature of the business form. Therefore, estimation of cash flows ranges in a continuum from being relatively simple in the case of a stock to very complex in the case of a startup. Although, the valuation of stock is stated to be relatively simpler, the environment, particularly corporate governance, and emerging market environment in the case of companies operating in emerging countries, makes it more complex than otherwise.

The environment and practices involving valuation of equity securities and other similar entities have been evolving and improving over time. Although there is some consensus among the researchers and practitioners on many valuation approaches and models for their usefulness and theoretical soundness, nevertheless, the prevailing valuation frameworks and the models are not considered as very accurate and convenient. Therefore, researchers and practitioner tend to seek more accurate valuation frameworks and models to support the valuation environment, particularly in the areas of valuation for private firm, startups, and firms in emerging markets.

\section{REFERENCES}

Aggarwal, R., Bhagat, S., \& Rangan, S. (2009). The Impact of Fundamentals on IPO Valuation. Financial Management, 38(2), 253-284.

Armstrong, C., Davila, A., \& Foster, G. (2006). Venture-backed Private Equity Valuation and Financial Statement Information. Review of Accounting Studies, $17,119-154$.

Bancel, F., \& Mittoo, U. R. (2014). The Gap between Theory and Practice of Corporate Valuation: The Survey of European Experts. The Journal of Applied Corporate Finance, 26(4), 106-117.

Bekaert, G., Erb, C. B., \& Harvey, C. R. (1997). What Matters for Emerging Equity Market Investments. Emering Markets Quarterly, 1(2), 17-46.

Bonaventura, M., \& Giudici, G. (2017). IPO Valuation and Profitability Expectations: Evidence from the Italian Exchange. Eurasian Bus Rev, 7, 247-266.

Bouncken, R. B., \& Gast, J. (2015). Coopetition: A Systematic Review, Synthesis, and Future Research Directions. Review of Management Science, 9(3), 577601.

Bradshaw, M. T. (2004). How Do Analysts Use Their Earnings Forecasts in Generating Stock Recommendations? The Accounting Review, 79(1), 25-50.

Brennan, M. J., \& Schwartz, E. S. (1984). Optimal Financial Policy and Firm Valuation. The Journal of Finance , 34(3), 593-607. 
IBT JOURNAL OF BUSINESS STUDIES (IBT-JBS) Volume 16 Issue 1, 2020

Brotherson, W. T., Eades, K. M., Harris, R. S., \& Higgins, R. C. (2013). "Best Practices" in Estimating the Cost of Capital: An Update. Journal of Applied Finance, 23(1), 15-33.

Bruner, R. F., Conroy, R. M., Estrada, J., Kritzman, M., \& Li, W. (2002). Introduction to Valuation in Emerging Markets. Emerging Markets Review, 3, 310-324.

Canefield, D., Kruschwitz, L., \& Loffler, A. (2014). Why Total Beta Produces Arbitrary Valuations: A Violation of the "No-Arbitrage" Principle. Business Valuation Review, 33(4), 131-135.

Cassia, L., Plati, A., \& Vismara, S. (2007). Equity Valuation Using DCF: A Theoretical Analysis of the Long-term Hypotheses. Investment Management and Financial Innovations, 4(1), 91-107.

Certo, S. T., Daily, C. M., \& Dan, D. R. (2003). Signaling firm value through board structure: An investigation of initial public offerings. Entrepreneurship Theory and Practice, 26(2), 33-50.

Cogliati, G. M., Paleari, S., \& Vismara, S. (2011). IPO pricing: Growth Rates Implied in Offer Prices. Annals of Finance, 7, 53-82.

Damodaran, A. (2008). Equity Risk Premiums (ERP): Determinants, Estimation and Implications. New York University Working Paper.

Damodaran, A. (2009). Valuing Young, Start-up and Growth Companies: Estimation Issues and Valuation Challenges. New York University Working paper.

Damodaran, A. (2012). Investment Valuation: Tools and Techniques for Determining the Value of any Asset (3rd ed.). Hoboken, New Jersey, USA: John Wiley \& Sons.

Darrough, M., \& Ye, J. (2007). Valuation of loss firms in a knowledge-based economy. Rev Acc Stud, 12, 61-93.

Dechow, P. M., \& You, H. (2013). Understanding and Predicting Target Price Valuation Errors. UC Berkley Working Paper.

Deeds, D. L., Decarlois, D., \& Coombs, J. E. (1997). The Impact of Firm-Specific Capabilities on the Amount of Capital Raised in an Initial Public OfferingEvidence from the Biotechnology Industry. Journal of Business Venturing, 12, $31-46$.

Demirakos, E. G., Strong, N. C., \& Walker, M. (2004). What Valuation Models Do Analysts Use? Accounting Horizons, 18(4), 221-240.

Demirakos, E. G., Strong, N. C., \& Walker, M. (2010). Does Valuation Model Choice Affect Target Price Accuracy? European Accounting Review, 19(1), 35-72. 
IBT JOURNAL OF BUSINESS STUDIES (IBT-JBS) Volume 16 Issue 1, 2020

Dittmann, I., Maug, E., \& Kemper, J. (2004). How fundamental are fundamental values? Valuation methods and their impact on the performance of German venture capitalists. European Financial Management, 10, 609-639.

Dohmeyer, B., \& Butler, P. (2013, September). The Implied Private Company Pricing Line 2.0 K0 $=(\mathrm{FCFF} 1 / \mathrm{P})+\mathrm{g}$. Buiness Valuation Update, 19(9).

Fazzini, M. (2018). Business Valuation: Theory and Practice. Palgrave Macmillan. https://doi.org/10.1007/978-3-319-89494-2

Feldman, S. J. (2005). Principles of Private Firm Valuation. Hoboken, New Jersey: John Wiley and Sons, Inc.

Ge, D., Mahoney, J. M., \& Mahoney, J. T. (2005). New Venture Valuation by Venture Capitalists: An Integrative Approach. Working Papers from University of Illinois at Urbana-Champaign, College of Business.

Goodman, D. H., \& McLelland, M. (2016). The Implied Private Company Pricing Line (IPCPL): On the Nature, Scope, and Assumptions of IPCPL Theory. Business Valuation Review, 35(1), 18-29.

Green, J., Hand, J. R., \& Zhang, X. F. (2016). Errors and Questionable Judgments in Analysts' DCF. Review of Accounting Studies, 21, 596-632.

Hand, J. R. (2005). The Value Relevance of Financial Statements in the Venture Capital. The Accounting Review, 80(2), 613-648.

Hitchner, J. R. (2017). Financial Valuation Applications and Models (Fourth ed.). Hoboken, New Jersey, USA: John Wiley and Sons.

How, J., Lam b, J., \& Yeo, J. (2007). The Use of the Comparable Firm Approach in Valuing Australian IPOs. International Review of Financial Analysis, 16, 99-115.

Imam, S., Barker, R., \& Clubb, C. (2008). The Use of Valuation Models by Uk Investment Analysts. European Accounting Review, 17(3), 503-535.

Jerald, P. E., Robinson, T. R., \& Stowe, J. D. (2015). Equity Valuation: A Survey of Professional Practice. CFA Institute Working Paper.

Kazlauskienè, V., \& Christauskas, Č. (2008). Business Valuation Model Based on the Analysis of Business Value Drivers. Engineering Economics, 57(2), 23-31.

Kim, M., \& Ritter, J. R. (1999). Valuing IPOs. Journal of Financial Economics, 53, 409-437.

Köhn, A. (2018). The Determinants of Startup Valuation in the Venture Capital Context: A Systematic Review and Avenues for Future Research. Management 
IBT JOURNAL OF BUSINESS STUDIES (IBT-JBS) Volume 16 Issue 1, 2020

Review, 68, 3-36.

Kolouchová, P., \& Novák, J. (2010). Cost of Equity Estimation Techniques Used by Valuation Experts. IES Working Paper.

Lee, P. M. (2001). What's in a Name.Com?: The Effects of '.Com' Name Changes On Stock Prices and Trading Activity. Strategic Management Journal, 22, 793804.

Lerner, J., Sørensen, M., \& Strömberg, P. (2008). Private Equity and Long-run Investment: The Case of Innovation. Working Paper 14623.

Mcallister, P. (1995). Valuation Accuracy: A Contribution to the Debate. Journal of Property Research, 12(3), 203-216.

Milanesi, G., Pesce, G., \& El Alabi, E. (2013). Technology-Based Startup Valuation Using Real Options with Edgeworth Expansion. Journal of Finance and Accounting, 1(2), 54-61.

Miloud, T., Aspelund, A., \& Cabrol, M. (2012). Startup Valuation by Venture Capitalists: An Empirical Study. An International Journal of Entrepreneurial Finance, 4(2), 151-174.

Montalván, S. M., \& Sarrió, D. R. (2006). The Discount Rates in Emerging Capital Markets. The IUP Journal of Financial Economics, 0(2), 35-55.

Nasser, S. (2010). Valuation for Startups: 9 Methods Explained. Retrieved from Medium: $\quad$ https://medium.com/parisoma-blog/valuation-for-startups-9methods-explained-53771c86590e

Penman, S. (2016). Valuation: The State of the Art. Schmalenbach Business Review, 17(1), 3-23.

Pereiro, L. E. (2006). The practice of investment Valuation in Emerging Markets: Evidence from Argentina. Journal of Multinational Financial Management, 16(2), 10-183.

Rath, Raymond, D. (2010). Private Company Valuation. In J. E. Pinto, E. Henry, T. R. Robinson, \& J. D. Stowe, Equity Asset Valuation: CFA Institute Investment Series (pp. 631-686). Hoboken, New Jersey, USA: John Wiley \& Sons Inc.

Rousseau, D. M., \& Mccarthy, S. (2007). Educating Managers from an Evidencebased Perspective. Academy of Management Learning \& Education, 6(1), 84101.

Saleh, W. (2017). Empirical estimation of the Residual Income Valuation Model: Profit-Making vs Loss-Making Firms. Journal of Finance and Bank Management, 5(2), 14-31.

Page $\mid 139$ 
Sanchez, J. G., Preve, L., \& Allende, V. S. (2010). Valuation in Emerging Markets: A Simulation Approach. Journal of Applied Corporate Finance, 22(2), 100-108.

Sievers, S., Mokwa, C. F., \& Keienburg, G. (2013). The Relevance of Financial Vs Non-Financial Information for the Valuation of Venture Capital-Backed Firms. European Accounting Review, 22(3), 467-511.

Sahoo, S., \& Rajib, P. (2013). Comparable Firm's P/E Multiple and IPO Valuation: An Empirical Investigation for Indian IPOs. Decision, 40(2), 27-46.

Trugman, G. R. (2017). Understanding Business Valuation: A Practical Guide to Valuing Small and Medium Sized Businessesn (Fifth ed.). New York: New York, American Institute of Certified Public Accountants, Inc.

Welch, I., \& Ritter, J. (2002). A Review of IPO Activty, Pricing and Allocations. Yale ICF Working Paper. 